\title{
Availability, Community Of Practice And Relative Advantage of ICT Resources Utilisation In Teaching-Learning Secondary School Agriculture: Lessons From Swaziland
}

\author{
Nomsa Mndzebele \\ Mzomba Dludlu
}

\author{
Comfort B. S. Mndebele
}

\begin{abstract}
Culture and society practices must adjust to changing challenges impacting the education sector with the advent of ICTs. The study determined the extent of availability and community of practice in respect of ICT resources. Furthermore, it described the perceptions of respondent secondary Agriculture teachers regarding the relative advantage of ICT tools in teaching and learning in the Southern African country (Swaziland) experience. A descriptive survey approach of data collection and analysis was employed. Findings revealed that ICT tools are somewhat adequately available for utilisation and integration in teaching agriculture. This comes the importance of the same. Availability of reliable adequate Internet remains a big challenge. Electricity and road networks are available and reliable. Community of practice in the ICT context is also low and problematic. Respondents experience ease of ICT use and less complexity in usage. It is recommended that: 1) ICT school policies be put in place and made mandatory; 2) Foster partnership with State-Owned Enterprises responsible for ICT Internet layout to negotiate reduced cost of installation; 3) Professional development workshops should be introduced with some incentives to enhance community of practice and popularise ICT utilisation and integration.
\end{abstract}

\section{INTRODUCTION}

A groundswell of interest has been on the increase in how computers and the Internet can be best harnessed to improve the efficiency and effectiveness of instructional delivery at all levels of education. In the technology-driven information age, every aspects of a country's economy is supposed to be networked with the global environment. Such networking is critical in the education sector which impacts the pace of development in other areas (Gabadeen, Alabi, Akinnubi, 2015). ICTs have the potential to accelerate, enrich, and deepens skills, to motivate and engage students, to help relate school experience to work practices as well as strengthening teaching to help schools change for the better. Whether or not we touch a computer, it is almost impossible to escape their daily influence on us (Liwanag, 2015). A mention of ICT readily brings to mind computer and Internet connection. These two, although not the only components, they have actually revolutionized the manner we handle and disseminate information.

Information and communication technology (ICT) refers to a systematic process of gathering, processing, storing, sending and retrieving of information through print broadcast, computing and telecommunications media (Amuchie, 2015) They are electronically based systems of information transmission, reception, processing and retrieval which has drastically changed the way we think, the way we live and the environment in which we live (Onwuagboke, Singh, 
Onwuagboke, 2014). ICT resources capable of being used in teaching and learning include but not limited to the following: radio, radio-cassette recorders, televisions, computers, multimedia projectors-Rom, Internet, interactive white boards slides and slide prop0jectors overhead projectors video players CVDs and electronic notice boards live (Onwuagboke, Singh, Onwuagboke, 2014).

ICT tools can be defined as the acquisition, processing, storage and dissemination of vocal, textual, pictorial and numerical information by micro-electronic-based combination of computers and telecommunication; it is the product of the marriage between computer technology-information acquisition, storage and processing, and telecommunication technology-information distribution (Egomo, Enyi, \& Tah, 2012). Availability of ICT tools in secondary schools as well as in tertiary institutions is critical for effective instructional delivery. The quality of the graduates, whether at high school or tertiary, is impacted by both the availability and accessibility. Availability and accessibility are not synonymous; ICT tools can be available and yet not accessible. The propensity to using ICTs in teaching and learning is determined by the availability of the resources in the schools. Furthermore, the utilization of technology in schools is largely dependent upon the availability and accessibility of ICT resources to include software, hardware and communications infrastructure (Onwuagboke, Singh, Onwuagboke, 2014). In Africa, most educational systems lack the resources for a sustainable integration of ICTs in education as African countries are faced with competing development priorities.

The type of e-learning appropriate for secondary school educations is blended learning. Blended learning is learning that involves a combination of face-to-face classroom time interspersed with computer access, use of school net-worked computers, and use of students own mobile phones ( Gabadeen, Alabi, Akinnubi, 2015). E-learning success is contingent upon communication technologies which can be categorized as synchronous or asynchronous. Synchronous technologies are inclusive of Skype, telephone, YouTube, Microsoft office Suite, Outlook, Web browsers, SPSS and Digital imaging hardware (video cameras and scanners). On the other hand, asynchronous technologies include Email, Discussion forums among others (Gabadeen, Alabi, Akinnubi, 2015).

\section{THEORETICAL FRAMEWORK AND LITERATURE REVIEW}

\section{Theoretical Foundation}

A theoretical framework is a collection of interrelated concepts, and provides guidance to research determining things to be measured as well as relationships (Phiri \& Phiri, 2016). The theory underpinning the study is perceived usefulness (PU) and perceived ease of use (PEU). Availability and utilisation of ICTs are determined by perceived usefulness is a primary determinants and perceived ease of use as a secondary determinant of a person's intention to use ICTs. Technology Acceptance Model (TAM) points out that perceived ease of use and perceived usefulness affects the intention to utilisation of ICTs. Perceived ease of use is defined as the extent to which a person believes that utilisation of a particular system would be free from effort (effort expectancy) and perceived usefulness as the degree to which a person believes that utilisation of a particular system would enhance job performance. This paper is, in the main, about the utilisation of ICTs which connotes a sense of acceptance within the environment of the user which has implications for the community of practice as a construct. This study therefore draws from the TAM theory. The TAM has been applied in the developing countries.

Awareness of ICT importance in ICT utilisation and integration is critical in teaching and learning and impacts on learner's performance. School leaders as well as teachers must have 
adequate awareness about the importance of ICT as a catalyst to facilitating the teaching and learning process (Tedla, 2012). As mobile technology advances, awareness is growing that these technologies may benefit the teaching and learning (Mc Callum, et al., 2014)

Perceived usefulness: In the Technology Acceptance Model (TAM), acceptance and use of ICT depend on the individual's perceptions of the usefulness and ease of use of the technology (Davis, 1989). The strength between perceived usefulness and intention to use varies with gender and age (Dludlu \& Mndzebele, (2018).

Performance expectancy is the degree to which an individual believes that using the technology would help attain gains in job performance (Davis, 1989). It remains the influence in the acceptance and use of ICT by teachers.

Relative advantage is the degree to which a technology is perceived as being better than the idea that precedes it. In Rogers (2003) innovations that offer more relative advantage, compatibility, simplicity, trialability, and observability would be adopted faster than other innovations.

Complexity is the degree to which an innovation is perceived difficult to understand and use (Rogers, 2003). It is negatively correlated with rate of adoption and thus excessive complexity of an innovation is an important obstacle to acceptance and use.

Compatibility, in Rogers (2003), is the degree to which an innovation is perceived as consistent with past experiences and needs of potential users. Lack of compatibility in information technology with individual needs may negatively affect acceptance and use of other suggestions.

Social Influence, in Liu and Kostiwa (2013), is a situation in which an individual considers using a particular technology because of other people's suggestions. Furthermore, social influence connotes the individual's internalisation of the reference group's subjective culture, and specific interpersonal agreements that the individual has made with others, in specific social situations.

Availability: Successful integration of ICT in teaching and learning depends, largely, on availability of infrastructure and teachers' adoption and embracing of ICT in education (Mathipa \& Mukhari, 2014). Irrespective of computer and related integration tools, teachers in urban schools indicate a variety of issues impeding the use and integration of ICT in their pedagogic activities. It is therefore absolutely critical in schools to have access to and availability of ICT tools to include updated software and hard ware for successful adoption and utilisation of such technology. Improved availability and fairness of access to technology resources by teachers, students as well as administrators is essential (Buabeng-Andoh, 2012).

Accessibility which is access to appropriate technology implies that affordances and constraints of a technological tool must be considered carefully for incorporation in lesson planning (Buabeng-Andoh, 2012). Authoritative data indicate that 4.3 billion people not yet using the Internet, 90\% live in developing countries. Furthermore, the World's 42 Least Connected Countries (LCC), with 2.5 billion people, access to ICT is largely out of reach, in particular for rural populations. In that regard, electronic transmission of data is unheard of in these countries (Phiri \& Phiri, 2016). The rapid growth especially in developing countries in the ownership and possession of personal smartphones has led to ICT becoming a keystone in everyday life without which performance of some basic and routine tasks is rendered 
dysfunctional. Internet use is growing steadily at 6.6\% globally in 2014 (in developed counties is at $3.3 \%$ ) and $8.7 \%$ in the developing world (Phiri \& Phiri, 2016)

\section{STATEMENT OF THE PROBLEM}

We live in a technology-driven age and everyone needs ICT competence. The ability to use computers is a critical part of everyone's education. The demand for ICT literacy is increasing in developing countries, inclusive of Swaziland, as employees realize that ICT tools. Instructional techniques using ICTs allow for individualization of learning and increase the attention span of learners. In the Swaziland context, Mndzebele (2013) identified external and internal barriers to utilisation and integration of ICTs in secondary teaching as: 1) Lack of knowledge and skills, 2) Lack of time, 3) Lack of ICT equipment, 4) Insufficient financial support, and 4) Low Internet connectivity. Teacher characteristics have been identified as key variables influencing classroom use of ICT tools (9Totter, Stutz, Grote, 2006).Teacher level barriers have been identified: a) Lack of time, b) Lack of self-confidence, c) Negative experiences, d) fear of embarrassment e) Lack of technical knowledge, and f) lack of motivation. These can be grouped as follows: a) Technological factors, b) Teacher characteristics, and c) School characteristics. Given this situation, it is a dire need to prepare the schools and teachers in particular to move from a traditional classroom with books, paper, and pencil to a mixed media, one that maximises the use of Internet and digital tools. Such a paradigm shift calls for provision and utilization of ICT appropriate technologies (Gabadeen, Alabi, \& Akinnubi, 2015).

The purpose of this study was to determine the availability, community of practice and relative advantage of ICT tools utilisation in the teaching of secondary school agriculture in the context of developing country, Swaziland in Southern Africa. The research questions that guided the study were: 1) What is the extent of awareness and availability of ICT resources among secondary Agriculture Teachers in Swaziland? 2) What is the accessibility, Community of Practice and Technical Support for secondary Agriculture teachers in respect of ICT resources in Swaziland? 3) What is the perceived ease of use, complexity and relative advantage of ICT resources utilization among secondary Agriculture teachers in Swaziland?

\section{METHODOLOGY}

\section{Design, Instrumentation, Data Collection and Analysis}

This study adopted a descriptive survey methodology to collect data on the extent of availability, community of practice and relative advantage of ICT tools. The study population was all secondary school Agriculture teachers in Swaziland. A total of 284 Agriculture teachers, a census study, was surveyed with a closed-ended questionnaire. Survey instrument was validated by panel of experts to include ICT School Inspectorate, ICT National Curriculum Developers and University/College Teacher Educators.

Reliability testing of the instrument was conducted with 40 final year students in Bachelor of Science in the Agricultural Education programme. Reliability coefficient was computed using Cronbach's, Alpha and estimated at the overall of .78. Questionnaire was delivered to the schools in person, and size of country and number of schools permits such means of data collection.

Data analysis was conducted by computing mean and standard deviation values for each of the items in the survey instrument. A Likert rating scale with the range $6=$ Strongly Agree to $1=$ Strongly Disagree was employed. For purposes of data interpretation, items with the mean value of 3.5 and above denoted "agreement", whereas items with mean values 3.49 and below denoted "disagreement". 


\section{FINDINGS AND DISCUSSION}

\section{Research Question 1: What is the extent of awareness and availability of ICT resources among secondary Agriculture Teachers in Swaziland?}

\section{Awareness and Availability of ICT Tools and Infrastructure}

Table 1 presents the opinions of agriculture teachers on their awareness of ICT utilisation. Awareness refers to being cautious of ICT devices that are available to promote ICT integration. Findings indicated that Agriculture teachers in Swaziland were aware of ICT integration tools available in schools for use in teaching. The overall mean of 5.38 and for the domain is evidence of the awareness of various ICT integration tools. In Table 1 all items relating to awareness were rated high in the "agree to "'strongly agree category rating. The overall mean value reported was 5.38. In terms of awareness of ICT tools, Agriculture teachers agree to their awareness of ICT devices for utilisation and integration in the teaching of agriculture.

Table 1: Awareness of ICT resources by secondary Agriculture teachers $(\mathrm{N}=284)$

\begin{tabular}{lllll}
\hline & \multicolumn{1}{c}{ Item } & \multicolumn{3}{c}{ Level of Agreement } \\
\cline { 3 - 5 } & & M & SD & Interpretation \\
\hline 1 & ICT use can improve my efficiency & 5.52 & .74 & Strongly agree \\
2 & I can see the need of using ICT in teaching & 5.50 & .73 & Strongly agree \\
3 & Using ICT in teaching is relevant & 5.46 & .71 & Agree \\
4 & $\begin{array}{l}\text { I am aware of the availability of ICT tools } \\
\text { for teaching }\end{array}$ & 5.05 & 1.16 & Agree \\
\hline & Overall & $\mathbf{5 . 3 8}$ & $\mathbf{. 8 4}$ & Agree \\
\hline
\end{tabular}

Rating scale: 1 = Strongly Disagree; 2 = Disagree; 3 = Slightly Disagree; 4 = Slightly Agree; 5 = Agree; 6 = Strongly Agree

Table 2 presents the views of Agriculture teachers with regard to ICT equipment and peripheral devices in schools for integration in teaching. Findings indicate that in secondary schools, there is limited supply of ICT tools for teachers to use in teaching and the overall mean was 2.55. Respondents, Agriculture teachers, agreed that there were not enough funding to support the use of ICT tools in teaching with a mean of 2.69. Teachers reported there were very few schools with LCD projectors for teaching with a mean value of 2.27 .

Table 2: Availability of ICT resources for teaching and learning Agriculture ( $\mathrm{N}=284)$

Item Level of Agreement

M SD Interpretation

$\mathbf{S}$

1 There are enough computers in the school for teaching

2.691 .56 Slightly

disagree

2 School has enough funds to support ICT use

2.681 .57 Slightly

disagree

3 School has LCD projectors for teaching anytime

$2.27 \quad 1.53 \quad$ Disagree Overall

$2.55 \quad 1.55$ Slightly

disagree

Rating scale: 1 = Strongly Disagree; 2 = Disagree; 3 = Slightly Disagree; 4 = Slightly Agree; 5 = Agree; 6 = Strongly Agree

Table 3 presents the opinions of Agriculture teachers on the availability of infrastructures in the school to support ICT integration. Infrastructure refers to the physical setup and resources that enables ICT utilisation and integration by Agriculture teachers. ICT infrastructure in 
secondary schools is relatively adequate in Swaziland (4.19). Many secondary schools in Swaziland were accessible through the roads (5.07). Schools were reported to have reliable electricity supply (4.62). The majority of schools have computer laboratories (4.08). Schools were reported to have ideal ICT laboratory structures (4.08). The absence of Internet connectivity in many schools was reported (2.98) by Agriculture teachers and pause a challenge in the utilisation and integration in teaching.

Table 3: ICT infrastructure availability in the school ( $\mathrm{N}=284)$

\begin{tabular}{|c|c|c|c|c|}
\hline \multicolumn{2}{|c|}{ Item } & \multicolumn{3}{|c|}{ Level of Agreement } \\
\hline & & $\mathbf{M}$ & SD & Interpretation \\
\hline 1 & The school is accessible through the road & 5.07 & 1.38 & Agree \\
\hline 2 & The school has reliable electricity & 4.62 & 1.49 & Agree \\
\hline 3 & The school has an ideal ICT laboratory & 4.08 & 1.69 & Slightly agree \\
\hline \multirow[t]{2}{*}{4} & The school has a reliable Internet provider & 2.98 & 1.84 & $\begin{array}{l}\text { Slightly } \\
\text { disagree }\end{array}$ \\
\hline & Overall & 4.19 & 1.60 & Slightly agree \\
\hline
\end{tabular}

Rating scale: 1= Strongly Disagree; 2 = Disagree; 3 = Slightly Disagree; 4 = Slightly Agree; 5 = Agree; 6 = Strongly Agree

\section{Research Question 2: What is the Accessibility, Community of Practice and Technical Support for secondary Agriculture teachers in respect of ICT resources in Swaziland?}

\section{Accessibility, Community of Practice and Technical Support}

Social influence is a construct represented in three elements: (1) community of practice (2) administrative support, and (3) attitudes of agriculture teachers towards ICT integration. Table 4 is opinions of Agriculture teachers on the existence of a community of practice where they share information. Community of practice is when a group of practitioners share useful information concerning their practice. Findings show that in schools there was limited community of practice in ICT integration among the agriculture teachers (3.32). Agriculture teachers agreed though that using ICT in teaching earns one respect from other teachers (4.06). Peers expect each other to use ICT in teaching (3.40) and that using computers increased electronic interaction with other teachers (3.34). Sharing information with other teachers using e-mail was rated low at secondary schools among the agriculture teachers (2.87). Community of practice, in the opinion of Agriculture teachers is in the "Disagreement" category implying that more work is yet to be done in popularizing ICT resources and their usage. Sharing of information or data using digital means remains a challenge to teachers. 
Table: 4 Community of practice in the use of ICT resources among Agriculture teachers $(\mathrm{N}=284)$

\begin{tabular}{|c|c|c|c|c|}
\hline \multicolumn{2}{|r|}{ Item } & \multicolumn{3}{|c|}{ Level of Agreement } \\
\hline & & \multirow{2}{*}{$\begin{array}{l}\mathbf{M} \\
4.06\end{array}$} & \multirow{2}{*}{$\begin{array}{l}\text { SD } \\
1.31\end{array}$} & \multirow{2}{*}{$\begin{array}{l}\text { Interpretation } \\
\text { Slightly agree }\end{array}$} \\
\hline 1 & $\begin{array}{l}\text { Using ICT in teaching earns one respect from } \\
\text { other teachers }\end{array}$ & & & \\
\hline 2 & My peers expect me to use ICT in teaching & 3.40 & 1.31 & Slightly disagree \\
\hline 3 & $\begin{array}{l}\text { Using computers has increased my electronic } \\
\text { interaction with other teachers }\end{array}$ & 3.34 & 1.48 & Slightly disagree \\
\hline 4 & $\begin{array}{l}\text { I am motivated by other teachers to use ICT } \\
\text { tools }\end{array}$ & 3.25 & 1.56 & Slightly disagree \\
\hline 5 & I share information with learners using e-mail & 3.12 & 1.44 & Slightly disagree \\
\hline 6 & I exchange computer files with other teachers & 3.19 & 1.60 & Slightly disagree \\
\hline \multirow[t]{2}{*}{7} & I communicate with other teachers using e-mail & 2.87 & 1.56 & Slightly disagree \\
\hline & Overall & 3.32 & 1.47 & Slightly disagree \\
\hline
\end{tabular}

Rating scale: 1 = Strongly Disagree; 2 = Disagree; 3 = Slightly Disagree; 4 = Slightly Agree; 5 = Agree; 6 = Strongly Agree

Table 5 presents opinions of Agriculture teachers on the availability of ICT technical support in schools. Technical support refers to the assistance provided to Agriculture teachers on how to operate ICT equipment for utilisation and integration in teaching secondary school agriculture. Findings indicated that in schools, there was very little technical support given to ICT users (3.58). Agriculture teachers acknowledged the support given by ICT teachers to ICT users in schools (3.96) was rather on the low side. Maintenance of available ICT devices was reported inadequate in schools with a mean of 3.32. Technical support to ICT users appears wanting. Agriculture teachers are more on their own in utilising and operating ICT devices and equipment for integration in their practice of the profession.

Table 5: Technical support to teachers in ICT resources utilisation by Agriculture teachers $(\mathrm{N}=\mathbf{2 8 4})$

\begin{tabular}{lllll}
\hline \multicolumn{2}{l}{ Item } & \multicolumn{3}{l}{ Level of Agreement } \\
& M & SD & Interpretation \\
\hline 1 & $\begin{array}{l}\text { ICT teachers do give technical support to } \\
\text { computer users }\end{array}$ & 3.96 & 1.43 & Slightly agree \\
2 & $\begin{array}{l}\text { I get enough assistance from other teachers } \\
\text { when using ICT for teaching }\end{array}$ & 3.45 & 1.46 & $\begin{array}{l}\text { Slightly } \\
\text { disagree }\end{array}$ \\
3 & ICT tools are well maintained in the school & 3.32 & 1.47 & $\begin{array}{l}\text { Slightly } \\
\text { disagree }\end{array}$ \\
\hline & Overall & $\mathbf{3 . 5 8}$ & $\mathbf{1 . 4 5}$ & Slightly agree \\
\hline
\end{tabular}

Rating scale: 1= Strongly Disagree; 2 = Disagree; 3 = Slightly Disagree; 4 = Slightly Agree; 5 = Agree; 6 = Strongly Agree.

\section{Research Question 3: What is the perceived ease of use, complexity and relative advantage of ICT resources utilisation among secondary Agriculture teachers in Swaziland?}

\section{Perceived Ease of Use and Complexity}

In Table 6 Effort Expectancy as a construct was described in the context of two domains, namely: (1) Perceived ease of use and (2) Complexity. Perceived ease of use is the degree an innovation is believed to require less effort to use. Agriculture teachers reported that ICT tools perceived to be usable with ease to them in teaching with an overall mean of 4.54. The majority of agriculture teachers reported had little difficulty operating computer soft-ware with mean value of 4.81. Respondents Agriculture teachers agreed ICT tools were found to be user- 
friendly with mean value of 4.78 while at the same time accomplished tasks much easier with ICT tools represented by mean value of 4.73 . With respect to perceived ease of use, Agriculture teachers agree ICT utilisation and integration in agriculture is easy.

Table 6: Perceived ease of use of ICT resources utilisation by Agriculture teachers $(\mathrm{N}=284)$

Item Level of Agreement

M SD Interpretation

$1 \quad$ I have no difficulty operating computer soft-ware $4.81 \quad 3.87 \quad$ Agree

2 I find ICT tools user-friendly

4.781 .00 Agree

3 I accomplish my tasks much easier with the use $4.73 \quad 1.15$ Agree of ICT

4 Everyone can learn to use a computer

$4.57 \quad 1.28$ Agree

5 I find most ICT tools easy to use

$4.30 \quad 1.29$ Slightly agree

6 Using ICT tools require no effort

$4.06 \quad 1.35$ Slightly agree

Overall

4.541 .66 Agree

Rating scale: 1= Strongly Disagree; 2 = Disagree; 3 = Slightly Disagree; 4 = Slightly Agree; 5 = Agree; 6 = Strongly Agree.

Table 7 presents perceived complexity of ICT utilisation and integration by Agriculture teachers. Complexity is defined as the degree to which an innovation is perceived difficult to understand and use. The overall finding was that respondents Agriculture teachers slightly agreed ICT utilisation and integration was less complex to use in teaching with a mean of 4.31. Teachers agreed learning to use ICT tools in teaching was somewhat of a challenge (3.17). Respondents agreed that computers make teaching of complex concepts easy (4.92) while acknowledging that computers fit well in the curriculum goals of the subject agriculture (4.83). Regarding complexity, Agriculture teachers slightly agree ICT utilisation and integration in agriculture is challenging difficulty to understand and use.

Table 7: Complexity of ICT resources utilisation by Agriculture teachers $(\mathrm{N}=284)$

\begin{tabular}{lllll}
\hline \multirow{2}{*}{ Item } & \multicolumn{3}{l}{ Level of Agreement } \\
\cline { 3 - 6 } & $\mathbf{M}$ & SD & Interpretation \\
\hline 1 & $\begin{array}{l}\text { Computers make teaching of complex concepts } \\
\text { easy }\end{array}$ & 4.92 & 1.07 & Agree \\
2 & $\begin{array}{l}\text { Computer use fits well in my curriculum goals } \\
\text { I have found ICT integration simple to use in }\end{array}$ & 4.83 & 3.18 & Agree \\
& $\begin{array}{l}\text { teaching } \\
\text { Learning to use ICT in teaching is a challenge }\end{array}$ & 3.17 & 1.38 & $\begin{array}{l}\text { Slightly agree } \\
\text { disagree }\end{array}$ \\
\hline & Overall & $\mathbf{4 . 3 1}$ & $\mathbf{1 . 7 2}$ & Slightly agree \\
\hline
\end{tabular}

Rating scale: 1 = Strongly Disagree; 2 = Disagree; 3 = Slightly Disagree; 4 = Slightly Agree; 5 = Agree; 6 = Strongly Agree

Table 8 describes the perception of agriculture teachers on the relative advantages of ICT utilisation and integration in teaching agriculture at senior secondary school level. Agriculture teachers were found to be knowledgeable about the relative advantages of ICT integration in teaching. An overall mean of 5.16 for the domain was an indication that ICT tools had relative advantages when used in classroom teaching of the agriculture curriculum content. 
Respondents agreed that using ICT in teaching improve learners' performance (5.06), improves teacher effectiveness had a mean of 5.52. Respondents agreed ICT tools had a relative advantage of saving time when used in teaching as indicating by mean of 5.39 .

Table 8: Relative advantage of ICT resources utilisation by Agriculture teachers $(\mathrm{N}=284)$

\begin{tabular}{lllll}
\hline \multirow{2}{*}{ Item } & \multicolumn{3}{c}{ Level of Agreement } \\
\cline { 3 - 5 } & $\mathbf{M}$ & $\mathbf{S D}$ & Interpretation \\
\hline 1 Using ICT in teaching improves effectiveness & 5.52 & 3.69 & Strongly agree \\
2 & Teaching with ICT tools saves time & 5.39 & .83 & Agree \\
3 & Using ICT in teaching improves learners & 5.06 & .89 & Agree \\
$\quad \begin{array}{llll}\text { performance } \\
4\end{array}$ & & & \\
Benefits of using ICT in teaching are apparent & 4.98 & .96 & Agree \\
I can share with others the benefits of & 4.83 & 1.02 & Agree \\
$\quad$ integrating ICT in teaching & & & \\
\hline Overall & $\mathbf{5 . 1 6}$ & $\mathbf{1 . 4 8}$ & Agree \\
\hline
\end{tabular}

Rating scale: 1 = Strongly Disagree; 2 = Disagree; 3 = Slightly Disagree; 4 = Slightly Agree; 5 = Agree; 6 = Strongly Agree.

\section{Conclusion}

\section{CONCLUSION AND RECOMMENDATIONS}

From the findings of the study, there are general conclusions to be drawn in respect of ICT resources irrespective of the teaching subject. The adoption and use of ICTs in schools have a positive impact on teaching and learning. Efforts geared towards utilisation and integration of ICTs in secondary schooling has not had much impact. Technology does not have an educational value in itself. It is of value when teachers use it in the teaching and learning environment. Availability, accessibility and utilisation of ICT tools in secondary school teaching will enhance sustainable secondary education in Swaziland. Teachers are the most important variable in the adoption and utilisation of ICTs.

With respect to ICT tools and Swaziland Agriculture teachers, some conclusions can be drawn. Provisions of ICT resources in terms of availability can be described as somewhat available, that is relatively adequate in particular computer hardware and software. There are however, areas of inadequacy. Swaziland Agriculture teachers have full awareness of ICT tools for utilisation and integration in teaching and learning.

Community of practice was rated pretty low indicative of the need to popularise the use of ICTs among teachers across board. Teachers need to be brought to the contemporary world of high technology and sharing of data by digital means.

Availability of infrastructure such as roads, telephone communication is somewhat adequate. However, Internet connectivity remains a big challenge in the Swaziland schools posing a constraint in integrating ICT in teaching agriculture.

\section{Recommendations}

Provision for access to ICT resources within the school environment should revamped; learning Centres such as the library, staff rooms, agriculture science laboratories and computer rooms should be equipped with ICT tools with easy accessibility for teachers of Agriculture. Placing ICT resources in the staff rooms would positively impact on the social influence, the significant others, and thus enhance interaction and engagement around ICT utilisation among teachers. 
Investment on Internet connectivity in secondary schools must be prioritized. ICT utilisation and integration in teaching requires sustainable Internet connectivity. Schools should seriously consider partnerships with State-Owned-Enterprises that are responsible for ICT infrastructure layout in the country. Schools may negotiate for special considerations in the cost of establishment Internet connectivity.

Teachers should be acquainted with the use of variety ICT resources; they must be periodic professional development workshop with a focus on ICT tools.

Technical support in terms of service and repair of ICT equipment and facilities must be strengthened through awareness of the importance of ICTs and ICT school policy formulations and implementations.

As a community of practitioners, teachers must be encouraged to engage with technology and apply it to teaching. ICT policies must be put in place which must be coupled with incentives and some kind of rewards for utilising ICTs and integrating the same in teaching.

\section{References}

Adomi, E. and Kapangban, E. (2010). Application f ICTs in Nigerian Secondary Schools. Library Philosophy and Practice, ISSN 1522-0222

Amuchie, A. A. (2015). Availability and Utilization of ICT Resources in Teaching and Learning in Secondary Schools in Ardo-Kola and Jalingo, Taraba State. Journal of Poverty, Investment and Development, Vol. 8. pp. 94-100. ISSN 24222-846X

Apagu, V.V. Walili, B. A. (2015). Availability and Utilization of ICT facilities for Teaching and Learning of Vocational and Technical Education in Yobe State Technical Colleges, American Journal of engineering research (AJER) vol. 4, issue 2 pp. 113-118

Aramide, K. A., Ladipo, S.O. \& Adebayo I. (2015) Demographic Variables and ICT Access as predictors of Information Communication Technologies' Usage Among Science Teachers In . Federral Unity schools In Nigeria, Library Philosophy and Practice (e-journal) paper 1217

Buabeng-Andoh, C. (2012) Factors influencing teacher's adoption and integration of information and communication technology into teaching: A review of the literature, international journal of Educational and Development using Information and Communication Technology (IJEDICT), Vol. 8. Issue 1 pp. 136-155

Dludlu, M. N. \& Mndzebele, N. (2018). Gender Performance Expectancy of Agriculture Teachers towards ICT Integration in Swaziland. International Journal of Information and Education Technology. Vol.8, No.6

Davis, F. (1989). Perceived usefulness, perceived ease of use, and user acceptance of information technology. MIS Quarterly, 13(3), 319-340.

Egmo, J. E. and Enyi, B. I. and Tah, M.M. (2012). Availability and Utilization of ICT tools for effective instructional delivery in tertiary institutions in Cross River State, Nigeria. Global Advanced Research Journal of Educational Research and Review, (ISSN. 2315-5132) Vol. 1. (8) pp. 190-195

Gabadeen, W. O, Alibi, A. T and Akinnubi, O.B. (2015) .Availability, Accessibility and Utilisation of E-learning Technologies for Sustainable Secondary Education in Federal Capital Territory, Abuja-Nigeria. Asia Pacific Journal of Education, Arts and Science, Vol. 2. No.2,

Liu, C. \& Kostiwa, K. (2013). An Application of the UTAUT model for understanding student perceptions using course management software. Journal of Educational Technology and Society, 7(2), 93104

Liwanag K.S. (2015). Extent of Information and Communication Technology Utilisation in Teaching: ITs Influence on Students' Academic Performance, Journal of Social Science and Humanities research, Vol. 1. Issue 2.

Mathipa E.R. and Mukhari S. (2014).Teacher Factors influencing the use of ICT in Teaching and Learning in South African Urban Schools. Mediterranean Journal of Social Sciences, Vol. 5. No. 23. pp. 1213-1220.

Mc Callum, K., Jeffrey, L. \& Kinshuk, (2014). Factors impacting teachers 'adoption of mobile learning. Journal of Information Technology Education, 13(20), 141-162. 
Mndzebele, M. N. (2013a). Challenges faced by schools when introducing ICT in Developing countries. International Journal of Humanities and Social science Invention, 2(9), 1-4.

Onwuagboke, B. B. C Sighn T.K.R. and Onwuagboke, J. N. (2014) Availability, Gender and Determinants of ICT Utilization in Teaching in Rural Secondary Schools in Souther Eastern Nigeria, The international Journal of Science and Technology, Vol. 2, Issue 5 pp.410-416

Phiri, W. and Phiri, G.G. (2016). Factors affecting ICT Implementation in selected secondary schools in Chipata district. . International Journal of Multidisciplinary Research and Development, Vol. 3. Issue 10 October pp. 161-175

Sibanda, M. Mapenduka, W. Furusa .S. (2016) Assessment Of The Availability And Utilization of ICTs For Teaching And Learning And Secondary Schools - Case Of A High School In Kwekwe, Zimbabwe. International Journal of Scientific and Technology Research, Vol. 5 Issue 5 pp.282-288.

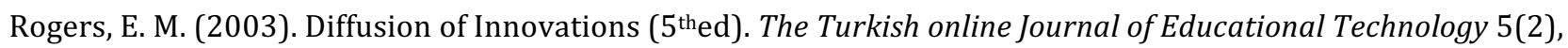
15 .

Tedla, B. A. (2012). Understanding the importance, impacts and barriers of ICT on teaching and learning in East African Countries. International Journal for e-Learning security, 2(3), 199-207.

Totter, A., Stutz, D. and Grote, G. (2006) ICT and Schools: Identification of Factors Influencing the use of new Media in Vocational Training Schools. The Electronic journal of e-Learning, Vol. 4. Issue 1 pp. 95-102. 